\title{
Annual Health Examination Didn't Perform a Positive Effect in the Prevention of Hyperlipidemia and Hyperglycemia Through an Eight-Year Study in China
}

\author{
Xiaohong Zhang \\ Beijing Tongren Hospital \\ Xiaokui He \\ Beijing Tongren Hospital \\ Xuehong Zhou \\ Beijing Tongren Hospital

\section{Hongyan Geng} \\ Beijing Tongren Hospital \\ Xiangyi Liu ( $\sim$ bestoplee@163.com ) \\ Beijing Tongren Hospital
}

\section{Research Article}

Keywords: annual health examination, hyperlipidemia, hyperglycemia

Posted Date: January 12th, 2022

DOI: https://doi.org/10.21203/rs.3.rs-955188/v2

License: (c) (i) This work is licensed under a Creative Commons Attribution 4.0 International License. Read Full License 


\section{Abstract}

Background: Annual health examination is recommended for the prevention and treatment of cardiovascular diseases and diabetes. However, whether it is effective for the prevention of hyperlipidemia and hyperglycemia remains unclear.

Methods: A retrospective analysis of clinical samples using the laboratory information system was performed. From 2012 to 2019,5043 participants ( 1755 males and 3288 females) have completed the annual health examination for 8 consecutive years, which was the follow-up group. In the same period, 136,994 participants (the control group) had a health examination only 1 time. Serum levels of fasting triglyceride (TG), total cholesterol (TC), low density lipoprotein cholesterol (LDL-C), high density lipoprotein cholesterol (HDL-C) and glucose (GLU) were measured.

Results: Compared with 2019 of the control group, serum TC and GLU in the 8th year of the follow-up group increased markedly in some of age groups $(p<0.001)$. Serum TG and TC in the 8th year were much higher compared with the 1 st year of the follow-up group, especially for the female $(p<0.001)$. Moreover, the prevalence of hyperlipidemia and hyperglycemia in the 8th year showed significant increase compared with the 1st year of the follow-up group and 2019 of the control group (all $p<0.05$ ).

Conclusions: Annual health examination didn't perform a positive effect in the prevention of hyperlipidemia and hyperglycemia. Health management should be paid more attention to prevent cardiovascular disease and diabetes.

\section{Introduction}

Cardiovascular diseases (CVD) have been identified as the first leading disease affecting the Chinese population [1]. It is widely known that serum hyperlipidemia, particularly elevated levels of total cholesterol (TC) and low-density lipoprotein cholesterol (LDL-C), is strongly related with the development of CVD [2]. So, management of serum cholesterol level has been a central objective in preventing cardiovascular events [3].

Over the past three decades, the prevalence of dyslipidemia has increased remarkably in China [4]. The results of 2012 national survey showed that the prevalence of hyperglyceridemia and hypercholesterolemia in adults were $13.1 \%$ and $4.9 \%$, respectively [5]. Projected trends in serum TC and other factors would induce an increase of approximately 21.3 million cardiovascular events and 7.7 million cardiovascular deaths over 2010 to 2030 [6]. Therefore, annual health examination was recommended for middle-aged people in the 2016 Chinese guideline for the management of dyslipidemia in adults [7].

Additionally, the prevalence of diabetes was also growing rapidly in China. Almost $25 \%$ of middle-aged and elderly rural Chinese residents had diabetes in 2010-2011 [8]. Glucose control can reduce microvascular complication of diabetes mellitus (DM) and may improve clinical outcomes for patients with DM and coronary heart disease [9]. So, early detection of hyperglycemia is necessary for early prevention and treatment of DM.

In recent years, annual health examination for the adults, especially for the middle-aged people and retired elderly, has been carried out in some companies and enterprises for over ten years [10]. Serum lipids and glucose have been detected routinely for all the health check-up people. However, whether annual measurement of serum lipids and glucose is effective for the prevention and treatment of CVD and DM, has not been proved.

\section{Materials And Methods}

\section{Participants}

All the participants came from the health examination center, Beijing Tongren Hospital, Capital Medical University. From 2012 to 2019, a total of 5043 people (1755 males and 3288 females) had a health examination for 8 consecutive years, which was the follow-up group. In the same period, the other people who went for health examination only 1 time were 
selected to be the control group. All the participants were divided into 10-year age classes ( $\leq 30$ years, $31-40$ years, $41-50$ years, $51-60$ years, $61-70$ years, $\geq 71$ years).

\section{Measurement}

For all the participants, serum levels of TG, TC, LDL-C, HDL-C and GLU were measured after at least a 12-h overnight fasting. The measurements were performed on a Beckman system (Beckman, American) in the Department of Clinical Laboratory, Beijing Tongren Hospital. The reagents of serum TG, TC, LDL-C and HDL-C were provided by the Hitachi Chemical Diagnostics Systems Co., Ltd (Hitachi Chemical Diagnostics Systems Co., Ltd, Japan). The reagent of serum GLU was provided by the Beckman (Beckman, American).

\section{Diagnostic criteria}

According to the 2016 Chinese guideline for the management of dyslipidemia in adults [7], elevated levels of TG ( $\geq 2.3$ $\mathrm{mmol} / \mathrm{L})$ and / or TC ( $\geq 6.2 \mathrm{mmol} / \mathrm{L})$ in serum were diagnosed as hyperlipidemia. According to the criteria of Chinese diabetes society [11], increased fasting serum glucose ( $\geq 7.0 \mathrm{mmol} / \mathrm{L})$ was defined as hyperglycemia.

\section{Approaches for evaluating the effectiveness of annual health examination to hyperlipidemia and hyperglycemia control}

In our study, evaluation approaches were in accordance with the three strategies used to evaluate the effectiveness of consecutive health examination, proposed by the Gan W [12]. 1) Concentrations: a. Compare the levels of serum TG, TC and GLU between the 8th year of the follow-up group and 2019 of the control group; b. Compare the levels of serum TG, TC and GLU between the 1st and the 8th health examination year of the follow-up group. 2) Prevalence: a. Compare the prevalence of hyperlipidemia and hyperglycemia between the 8th year of the follow-up group and 2019 of the control group; b.

Compare the prevalence of hyperlipidemia and hyperglycemia between the 1st and the 8th health examination year of the follow-up group. 3) Calculate the numbers of participants who had a bad hyperlipidemia or hyperglycemia control during the 8 years in the follow-up group. A "bad hyperlipidemia or hyperglycemia control" is defined as persons with fasting serum $\mathrm{TG} \geq 2.3 \mathrm{mmol} / \mathrm{L}$, or TC $\geq 6.2 \mathrm{mmol} / \mathrm{L}$, or $\mathrm{GLU} \geq 7.0 \mathrm{mmol} / \mathrm{L}$ for $\geq 3$ times among the total 8 examinations.

\section{Statistical analysis}

All the data of clinical samples were obtained from the laboratory information system (LIS). All statistical analyses were performed using the IBM SPSS 22.0 software program. However, serum lipids and glucose concentrations didn't distribute normally and were expressed as the median (interquartile range). Differences between gender groups were assessed by 2 independent samples Mann-Whitney test. Differences among age groups were tested by Kruskal-Wallis test. Furthermore, differences of the prevalence of hyperlipidemia and hyperglycemia between the groups were assessed by the Poisson chisquare test. All $p$ values were two-sided, and a $p$ value $<0.05$ was considered statistically significant.

\section{Results}

\section{The levels of serum lipids and glucose in the control group}

From 2012 to 2019, 5043 people have taken part in the health examination for 8 consecutive years. In the same period, 136,994 participants (the control group) had a health examination only 1 time. The number of participants in each age group was shown in Table 1. The age of all the participants ranged from 18 to 100. 
Table 1

Numbers of participants in the control group, the 1st and 8th year of the follow-up group

\begin{tabular}{|c|c|c|c|c|c|c|c|c|}
\hline \multicolumn{2}{|c|}{ Age group } & $\leq 30 y$ & $31-40 y$ & $41-50 y$ & $51-60 y$ & $61-70 y$ & $\geq 71 y$ & Total \\
\hline \multicolumn{9}{|c|}{ The control group } \\
\hline \multirow[t]{2}{*}{2012} & Male & 1901 & 2090 & 1868 & 1759 & 682 & 510 & 8810 \\
\hline & Female & 2446 & 2067 & 2490 & 1911 & 789 & 598 & 10,301 \\
\hline \multirow[t]{2}{*}{2013} & Male & 1870 & 2365 & 1801 & 1687 & 774 & 598 & 9095 \\
\hline & Female & 2731 & 2508 & 2078 & 1757 & 800 & 600 & 10,474 \\
\hline \multirow[t]{2}{*}{2014} & Male & 1473 & 2138 & 1571 & 1605 & 773 & 563 & 8123 \\
\hline & Female & 2132 & 2444 & 1965 & 1769 & 831 & 602 & 9743 \\
\hline \multirow[t]{2}{*}{2015} & Male & 1044 & 1751 & 1431 & 1603 & 799 & 509 & 7137 \\
\hline & Female & 1859 & 2383 & 1850 & 1723 & 933 & 606 & 9354 \\
\hline \multirow[t]{2}{*}{2016} & Male & 1207 & 1946 & 1428 & 1629 & 888 & 551 & 7649 \\
\hline & Female & 1885 & 2437 & 1836 & 1710 & 1050 & 644 & 9562 \\
\hline \multirow[t]{2}{*}{2017} & Male & 1121 & 1714 & 1278 & 1276 & 786 & 408 & 6583 \\
\hline & Female & 1613 & 2236 & 1752 & 1419 & 958 & 570 & 8548 \\
\hline \multirow[t]{2}{*}{2018} & Male & 1248 & 1850 & 1283 & 1236 & 832 & 424 & 6873 \\
\hline & Female & 1852 & 2435 & 1820 & 1465 & 1082 & 550 & 9204 \\
\hline \multirow[t]{2}{*}{2019} & Male & 980 & 1846 & 1413 & 1263 & 815 & 371 & 6688 \\
\hline & Female & 1508 & 2689 & 1793 & 1297 & 1034 & 529 & 8850 \\
\hline \multicolumn{9}{|c|}{ The follow-up group } \\
\hline \multirow[t]{2}{*}{$1 \mathrm{st}$} & Male & 197 & 403 & 418 & 417 & 205 & 115 & 1755 \\
\hline & Female & 521 & 830 & 794 & 673 & 279 & 191 & 3288 \\
\hline \multirow[t]{2}{*}{ 8th } & Male & 28 & 300 & 398 & 404 & 403 & 222 & 1755 \\
\hline & Female & 73 & 700 & 818 & 713 & 625 & 359 & 3288 \\
\hline
\end{tabular}

The levels of serum lipids and glucose based on the data of control group from 2012 to 2019 were shown in Table 2. Serum TG increased with aging in both genders. For the male, serum TG was $1.05 \mathrm{mmol} / \mathrm{L}$ in $\leq 30$ year group and a 1.42 -fold increase was found in 41-50 year group $(p<0.001)$. After the age of 50 , serum TG began to decrease slightly. Unlike the male, serum TG of female was $0.67 \mathrm{mmol} / \mathrm{L}$ in $\leq 30$ year group and increased continuously after menopausal period. In 6170 year group, it had a maximum value $(1.30 \mathrm{mmol} / \mathrm{L})$ and almost doubled $(p<0.001)$. 
Table 2

The levels of serum lipids and glucose in the control group

\begin{tabular}{|c|c|c|c|c|c|c|c|c|c|c|}
\hline \multirow{2}{*}{$\begin{array}{l}\text { Age } \\
\text { group }\end{array}$} & \multicolumn{2}{|l|}{ TG } & \multicolumn{2}{|l|}{ TC } & \multicolumn{2}{|l|}{ LDL-C } & \multicolumn{2}{|l|}{ HDL-C } & \multicolumn{2}{|l|}{ GLU } \\
\hline & Male & Female & Male & Female & Male & Female & Male & Female & Male & Female \\
\hline \multirow[t]{2}{*}{$\leq 30 y$} & 1.05 & 0.67 & 4.47 & 4.31 & 2.78 & 2.45 & 1.20 & 1.56 & 4.96 & 4.84 \\
\hline & $\begin{array}{l}(0.72- \\
1.60)\end{array}$ & $\begin{array}{l}(0.51- \\
0.92)^{\#}\end{array}$ & $\begin{array}{l}(3.95- \\
5.06)\end{array}$ & $\begin{array}{l}(3.86- \\
4.80)^{\#}\end{array}$ & $\begin{array}{l}(2.31- \\
3.30)\end{array}$ & $\begin{array}{l}(2.06- \\
2.87)^{\#}\end{array}$ & $\begin{array}{l}(1.01- \\
1.42)\end{array}$ & $\begin{array}{l}(1.33- \\
1.80)^{\#}\end{array}$ & $\begin{array}{l}(4.69- \\
5.24)\end{array}$ & $\begin{array}{l}(4.59- \\
5.10)^{\#}\end{array}$ \\
\hline \multirow{2}{*}{$\begin{array}{l}31- \\
40 y\end{array}$} & 1.38 & 0.78 & 4.79 & 4.51 & 3.04 & 2.62 & 1.13 & 1.52 & 5.10 & 4.95 \\
\hline & $\begin{array}{l}(0.93- \\
2.09)^{\star \star \star}\end{array}$ & $\begin{array}{l}(0.57- \\
1.10)^{\star \star \star}, \#\end{array}$ & $\begin{array}{l}(4.26- \\
5.36)^{\star \star \star}\end{array}$ & $\begin{array}{l}(4.03- \\
5.05)^{\star \star \star, \#}\end{array}$ & $\begin{array}{l}(2.56- \\
3.55)^{\star \star \star}\end{array}$ & $\begin{array}{l}(2.21- \\
3.10)^{\star \star \star}, \#\end{array}$ & $\begin{array}{l}(0.96- \\
1.34)^{\star \star \star}\end{array}$ & $\begin{array}{l}(1.28- \\
1.78)^{\star \star \star}, \#\end{array}$ & $\begin{array}{l}(4.82- \\
5.43)^{\star \star \star}\end{array}$ & $\begin{array}{l}(4.69- \\
5.24)^{\star \star \star}, \#\end{array}$ \\
\hline \multirow{2}{*}{$\begin{array}{l}41- \\
50 y\end{array}$} & 1.49 & 0.95 & 4.94 & 4.86 & 3.13 & 2.94 & 1.15 & 1.49 & 5.31 & 5.11 \\
\hline & $\begin{array}{l}(1.00- \\
2.22)^{\star \star \star}\end{array}$ & $\begin{array}{l}(0.68- \\
1.39)^{\star \star *}, \#\end{array}$ & $\begin{array}{l}(4.39- \\
5.54)^{\star \star \star}\end{array}$ & $\begin{array}{l}(4.32- \\
5.43)^{\star \star \star, \#}\end{array}$ & $\begin{array}{l}(2.63- \\
3.67)^{\star \star \star}\end{array}$ & $\begin{array}{l}(2.49- \\
3.46)^{\star \star \star}, \#\end{array}$ & $\begin{array}{l}(0.97- \\
1.37)^{\star \star \star}\end{array}$ & $\begin{array}{l}(1.24- \\
1.76)^{* \star *}, \#\end{array}$ & $\begin{array}{l}(4.97- \\
5.77)^{\star \star \star}\end{array}$ & $\begin{array}{l}(4.82- \\
5.44)^{\star \star \star}, \#\end{array}$ \\
\hline \multirow{2}{*}{$\begin{array}{l}51- \\
60 y\end{array}$} & 1.44 & 1.23 & 4.95 & 5.34 & 3.14 & 3.35 & 1.18 & 1.47 & 5.54 & 5.31 \\
\hline & $\begin{array}{l}(0.99- \\
2.15)^{\star \star \star}\end{array}$ & $\begin{array}{l}(0.86- \\
1.75)^{\star \star \star}, \#\end{array}$ & $\begin{array}{l}(4.34- \\
5.56)^{\star \star \star}\end{array}$ & $\begin{array}{l}(4.73- \\
5.98)^{\star \star \star, \#}\end{array}$ & $\begin{array}{l}(2.58- \\
3.68)^{\star \star \star}\end{array}$ & $\begin{array}{l}(2.80- \\
3.92)^{\star \star \star, \#}\end{array}$ & $\begin{array}{l}(0.99- \\
1.40)^{\star \star \star}\end{array}$ & $\begin{array}{l}(1.23- \\
1.75)^{\star \star \star}, \#\end{array}$ & $\begin{array}{l}(5.12- \\
6.20)^{\star \star \star}\end{array}$ & $\begin{array}{l}(4.99- \\
5.76)^{\star \star \star}, \#\end{array}$ \\
\hline \multirow{2}{*}{$\begin{array}{l}61- \\
70 y\end{array}$} & 1.28 & 1.30 & 4.77 & 5.27 & 2.99 & 3.24 & 1.20 & 1.45 & 5.61 & 5.46 \\
\hline & $\begin{array}{l}(0.91- \\
1.85)^{\star \star \star}\end{array}$ & $\begin{array}{l}(0.93- \\
1.83)^{\star \star \star}\end{array}$ & $\begin{array}{l}(4.13- \\
5.40)^{\star \star \star}\end{array}$ & $\begin{array}{l}(4.66- \\
5.91)^{\star \star \star, \#}\end{array}$ & $\begin{array}{l}(2.42- \\
3.55)^{\star \star \star}\end{array}$ & $\begin{array}{l}(2.68- \\
3.82)^{\star \star \star}, \#\end{array}$ & $\begin{array}{l}(1.00- \\
1.44)\end{array}$ & $\begin{array}{l}(1.21- \\
1.73)^{\star \star \star}, \#\end{array}$ & $\begin{array}{l}(5.17- \\
6.37)^{\star \star \star}\end{array}$ & $\begin{array}{l}(5.10- \\
6.00)^{\star \star \star}, \#\end{array}$ \\
\hline \multirow[t]{2}{*}{$\geq 71 y$} & 1.15 & 1.25 & 4.48 & 5.00 & 2.76 & 2.99 & 1.21 & 1.46 & 5.77 & 5.66 \\
\hline & $\begin{array}{l}(0.82- \\
1.62)^{\star \star \star}\end{array}$ & $\begin{array}{l}(0.91- \\
1.72)^{\star * *, \#}\end{array}$ & $\begin{array}{l}(3.88- \\
5.16)\end{array}$ & $\begin{array}{l}(4.34- \\
5.69)^{\star * *, \#}\end{array}$ & $\begin{array}{l}(2.19- \\
3.36)^{*}\end{array}$ & $\begin{array}{l}(2.38- \\
3.62)^{\star * *}, \#\end{array}$ & $\begin{array}{l}(1.01- \\
1.47)^{\star \star \star}\end{array}$ & $\begin{array}{l}(1.21- \\
1.76)^{\star * \star}, \#\end{array}$ & $\begin{array}{l}(5.28- \\
6.65)^{\star \star \star}\end{array}$ & $\begin{array}{l}(5.19- \\
6.45)^{\star \star *, \#}\end{array}$ \\
\hline
\end{tabular}

In consistence with serum TG, serum TC of male showed an obvious age-dependent increase and reached the highest level ( $4.95 \mathrm{mmol} / \mathrm{L}$ ) in 51-60 year group. After that, it dropped slowly. In $\geq 71$ year group, serum TC returned to the same value with the $\leq 30$ year group. For the female, under the age of menopause, serum TC was lower compared with that of the agematched male $(p<0.001)$. In 51-60 year group, it had a maximum value $(5.34 \mathrm{mmol} / \mathrm{L})$, even higher than the age-matched male. Despite serum TC of female decreased after menopausal period, it still exceeded the level of $\leq 30$ year group far away $(p<0.001)$.

The change patterns of serum LDL-C in both genders were similar to the level of serum TC. Serum LDL-C peaked in 51-60 year group of both genders. After menopausal period, serum LDL-C of female decreased but it was always higher than the age-matched male $(p<0.001)$. On the contrary, serum HDL-C decreased at first and then increased with aging, which was significantly different with TG, TC and LDL-C. In addition, serum HDL-C of male was always lower than that of the agematched female.

Serum GLU exhibited an age-dependent increase markedly in both genders. 1.16- and 1.17-fold higher levels for male and female were found in $\geq 71$ year group compared with the $\leq 30$ year group (both $p<0.001$ ), respectively. Furthermore, during the whole life-span, serum GLU of female was always lower than that of the age-matched male, even after the age of menopause. 


\section{Effect of annual health examination on the levels of serum TG, TC and GLU in the follow-up group}

Because the number of participants of $\leq 30$ year group in the 8th year of the follow-up group was small (Table 1), to avoid introducing bias in calculating the levels and the incidence rate, we merged $\leq 30$ year group and 31-40 year group to be $\leq 40$ year group.

The levels of serum TG, TC and GLU in 2019 of the control group, the 1st and 8th health examination year of the follow-up group were listed in Table 3. Firstly, we performed a cross-sectional comparison, comparing the levels of serum TG, TC and GLU between the 8th year of the follow-up group and 2019 of the control group. Our results established that compared with 2019 of the control group, serum TC and GLU in the 8th year of the follow-up group increased obviously in the $\leq 40$ year group (all $p<0.001$ ), which was present in both genders. Additionally, serum TC and GLU in the 8th year of the follow-up group were much higher than 2019 of the control group in the 41-50 year group (both $p<0.001$ ), which was present only in female. Surprisingly, in the 61-70 year groups, serum GLU of female in the 8th year of the follow-up group was also higher than 2019 of the control group $(p<0.001)$. In the other age groups, there were no significant differences of serum TG, TC and GLU levels between the 8th year of the follow-up and the control group in 2019 (all $p>0.05$ ). 
Table 3

Levels of serum TG, TC and GLU in 2019 of the control group, the 1st and 8th year of the follow-up group

\begin{tabular}{|c|c|c|c|c|c|c|c|c|c|c|c|}
\hline \multicolumn{2}{|c|}{ Age group } & \multicolumn{2}{|l|}{$\leq 40 y$} & \multicolumn{2}{|l|}{$41-50 y$} & \multicolumn{2}{|l|}{$51-60 y$} & \multicolumn{2}{|l|}{$61-70 y$} & \multicolumn{2}{|l|}{$\geq 71 y$} \\
\hline & & Male & Female & Male & Female & Male & Female & Male & Female & Male & Female \\
\hline \multirow[t]{6}{*}{ TG } & 2019 & 1.25 & 0.74 & 1.41 & 0.95 & 1.46 & 1.22 & 1.26 & 1.33 & 1.21 & 1.27 \\
\hline & & $\begin{array}{l}(0.83- \\
1.94)\end{array}$ & $\begin{array}{l}(0.55- \\
1.04)\end{array}$ & $\begin{array}{l}(0.97- \\
2.12)\end{array}$ & $\begin{array}{l}(0.70- \\
1.35)\end{array}$ & $\begin{array}{l}(1.02- \\
2.15)\end{array}$ & $\begin{array}{l}(0.87- \\
1.76)\end{array}$ & $\begin{array}{l}(0.89- \\
1.81)\end{array}$ & $\begin{array}{l}(0.93- \\
1.86)\end{array}$ & $\begin{array}{l}(0.81- \\
1.67)\end{array}$ & $\begin{array}{l}(0.92- \\
1.76)\end{array}$ \\
\hline & $1 \mathrm{st}$ & 1.15 & 0.71 & 1.44 & 0.97 & 1.44 & 1.20 & 1.37 & 1.29 & 1.21 & 1.27 \\
\hline & & $\begin{array}{l}(0.79- \\
1.76)\end{array}$ & $\begin{array}{l}(0.53- \\
0.99)\end{array}$ & $\begin{array}{l}(1.00- \\
2.11)\end{array}$ & $\begin{array}{l}(0.70- \\
1.39)\end{array}$ & $\begin{array}{l}(1.04- \\
2.05)\end{array}$ & $\begin{array}{l}(0.85- \\
1.64)\end{array}$ & $\begin{array}{l}(0.93- \\
2.12)\end{array}$ & $\begin{array}{l}(0.93- \\
1.86)\end{array}$ & $\begin{array}{l}(0.85- \\
1.54)\end{array}$ & $\begin{array}{l}(0.93- \\
1.74)\end{array}$ \\
\hline & 8th & 1.29 & 0.77 & 1.42 & 0.95 & 1.47 & 1.23 & 1.27 & 1.27 & 1.26 & 1.24 \\
\hline & & $\begin{array}{l}(0.93- \\
2.04)^{\#}\end{array}$ & $\begin{array}{l}(0.58- \\
1.10)^{*}, \#\end{array}$ & $\begin{array}{l}(0.96- \\
2.10)\end{array}$ & $\begin{array}{l}(0.70- \\
1.37)\end{array}$ & $\begin{array}{l}(1.03- \\
2.06)\end{array}$ & $\begin{array}{l}(0.87- \\
1.69)\end{array}$ & $\begin{array}{l}(0.94- \\
1.82)\end{array}$ & $\begin{array}{l}(0.92- \\
1.81)\end{array}$ & $\begin{array}{l}(0.83- \\
1.72)\end{array}$ & $\begin{array}{l}(0.92- \\
1.67)\end{array}$ \\
\hline \multirow[t]{6}{*}{$\mathrm{TC}$} & 2019 & 4.78 & 4.56 & 5.06 & 4.99 & 4.98 & 5.45 & 4.87 & 5.36 & 4.40 & 4.98 \\
\hline & & $\begin{array}{l}(4.23- \\
5.43)\end{array}$ & $\begin{array}{l}(4.08- \\
5.10)\end{array}$ & $\begin{array}{l}(4.45- \\
5.63)\end{array}$ & $\begin{array}{l}(4.42- \\
5.54)\end{array}$ & $\begin{array}{l}(4.36- \\
5.63)\end{array}$ & $\begin{array}{l}(4.85- \\
6.10)\end{array}$ & $\begin{array}{l}(4.12- \\
5.50)\end{array}$ & $\begin{array}{l}(4.78- \\
6.02)\end{array}$ & $\begin{array}{l}(3.78- \\
5.08)\end{array}$ & $\begin{array}{l}(4.21- \\
5.60)\end{array}$ \\
\hline & $1 \mathrm{st}$ & 4.57 & 4.35 & 4.86 & 4.84 & 4.93 & 5.20 & 4.78 & 5.17 & 4.42 & 5.04 \\
\hline & & $\begin{array}{l}(4.04- \\
5.14)\end{array}$ & $\begin{array}{l}(3.89- \\
4.92)\end{array}$ & $\begin{array}{l}(4.41- \\
5.44)\end{array}$ & $\begin{array}{l}(4.27- \\
5.41)\end{array}$ & $\begin{array}{l}(4.34- \\
5.51)\end{array}$ & $\begin{array}{l}(4.67- \\
5.85)\end{array}$ & $\begin{array}{l}(4.16- \\
5.30)\end{array}$ & $\begin{array}{l}(4.62- \\
5.77)\end{array}$ & $\begin{array}{l}(3.74- \\
5.16)\end{array}$ & $\begin{array}{l}(4.37- \\
5.62)\end{array}$ \\
\hline & 8th & 5.04 & 4.71 & 5.00 & 5.05 & 4.98 & 5.49 & 4.90 & 5.31 & 4.35 & 5.01 \\
\hline & & $\begin{array}{l}(4.48- \\
5.60)^{*}, \#\end{array}$ & $\begin{array}{l}(4.23- \\
5.29)^{\star}, \#\end{array}$ & $\begin{array}{l}(4.44- \\
5.59)\end{array}$ & $\begin{array}{l}(4.49- \\
5.64)^{*}, \#\end{array}$ & $\begin{array}{l}(4.37- \\
5.58)\end{array}$ & $\begin{array}{l}(4.86- \\
6.10)^{\#}\end{array}$ & $\begin{array}{l}(4.17- \\
5.49)\end{array}$ & $\begin{array}{l}(4.74- \\
5.97)^{\#}\end{array}$ & $\begin{array}{l}(3.80- \\
5.03)\end{array}$ & $\begin{array}{l}(4.26- \\
5.63)\end{array}$ \\
\hline \multirow[t]{6}{*}{ GLU } & 2019 & 5.02 & 4.89 & 5.27 & 5.06 & 5.49 & 5.27 & 5.70 & 5.42 & 5.78 & 5.62 \\
\hline & & $\begin{array}{l}(4.75- \\
5.32)\end{array}$ & $\begin{array}{l}(4.63- \\
5.14)\end{array}$ & $\begin{array}{l}(4.94- \\
5.73)\end{array}$ & $\begin{array}{l}(4.80- \\
5.39)\end{array}$ & $\begin{array}{l}(5.08- \\
6.18)\end{array}$ & $\begin{array}{l}(4.95- \\
5.74)\end{array}$ & $\begin{array}{l}(5.23- \\
6.55)\end{array}$ & $\begin{array}{l}(5.08- \\
5.97)\end{array}$ & $(5.28-.66)$ & $\begin{array}{l}(5.14- \\
6.45)\end{array}$ \\
\hline & $1 \mathrm{st}$ & 5.12 & 5.04 & 5.28 & 5.17 & 5.50 & 5.34 & 5.71 & 5.52 & 5.74 & 5.71 \\
\hline & & $\begin{array}{l}(4.81- \\
5.42)\end{array}$ & $\begin{array}{l}(4.78- \\
5.35)\end{array}$ & $\begin{array}{l}(4.97- \\
5.78)\end{array}$ & $\begin{array}{l}(4.88- \\
5.51)\end{array}$ & $\begin{array}{l}(5.11- \\
6.10)\end{array}$ & $\begin{array}{l}(5.02- \\
5.75)\end{array}$ & $\begin{array}{l}(5.27- \\
6.37)\end{array}$ & $\begin{array}{l}(5.15- \\
6.00)\end{array}$ & $\begin{array}{l}(5.28- \\
6.52)\end{array}$ & $\begin{array}{l}(5.20- \\
6.41)\end{array}$ \\
\hline & 8th & 5.16 & 5.08 & 5.41 & 5.20 & 5.54 & 5.46 & 5.75 & 5.57 & 5.86 & 5.78 \\
\hline & & $\begin{array}{l}(4.87- \\
5.48)^{\star}\end{array}$ & $\begin{array}{l}(4.81- \\
5.40)^{\star}\end{array}$ & $\begin{array}{l}(5.03- \\
5.78)\end{array}$ & $\begin{array}{l}(4.92- \\
5.53)^{\star}\end{array}$ & $\begin{array}{l}(5.16- \\
6.12)\end{array}$ & $\begin{array}{l}(5.10- \\
5.88)^{\#}\end{array}$ & $\begin{array}{l}(5.25- \\
6.62)\end{array}$ & $\begin{array}{l}(5.18- \\
6.14)^{*}\end{array}$ & $\begin{array}{l}(5.36- \\
6.83)\end{array}$ & $\begin{array}{l}(5.21- \\
6.67)\end{array}$ \\
\hline \multicolumn{12}{|c|}{ *: $p<0.001$ compared with age-matched group in 2019 of the control group } \\
\hline & & & & & & & & 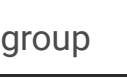 & & & \\
\hline
\end{tabular}

Secondly, we compared the levels of serum TG, TC and GLU between the 1st and the 8th year of the follow-up group longitudinally. Our results showed that in the $\leq 40$ year group, serum TG and TC of both genders in the 8th year significantly increased compared with those in the 1st year (all $p<0.001$ ). Additionally, in the 41-50, 51-60 and 61-70 year groups, serum TC of female in the 8th year increased markedly compared with those in the 1 st year (all $p<0.001$ ). These results suggested that serum TC of female demonstrated a more obvious increase compared with the age-matched male from 2012 to 2019. On the whole, there were no significant differences of serum GLU levels between the 1st and the 8th year of the follow-up (all $p>0.05$ ). 


\section{The prevalence of hyperlipidemia and hyperglycemia in the control group}

According to the diagnostic criteria, the incidence rates of hyperlipidemia in the control group from 2012 to 2019 were listed in Table 4.

Table 4

Percentages of hyperlipidemia in the control group from 2012 to 2019

\begin{tabular}{|clllllll|}
\hline Age group & $\mathbf{5 4 0 y}$ & $\mathbf{4 1 - 5 0 y}$ & $\mathbf{5 1 - 6 0 y}$ & $\mathbf{6 1 - 7 0 y}$ & $\mathbf{2 7 1 y}$ & Total \\
\hline 2012 & Male & 19.22 & 29.41 & 26.83 & 17.45 & 12.35 & 22.58 \\
\hline \multirow{2}{*}{2013} & Female & 3.99 & 11.73 & 22.50 & 25.22 & 21.07 & 11.91 \\
\hline & Male & 20.07 & 29.15 & 28.33 & 19.25 & 12.21 & 22.81 \\
\hline 2014 & Memale & 4.62 & 11.93 & 25.95 & 27.50 & 23.67 & 12.49 \\
\hline & Female & 19.44 & 28.26 & 27.73 & 21.73 & 12.61 & 22.53 \\
\hline 2015 & Male & 19.18 & 26.83 & 26.45 & 17.52 & 14.15 & 21.80 \\
\hline \multirow{2}{*}{2016} & Female & 5.02 & 10.16 & 25.42 & 23.69 & 20.63 & 12.67 \\
\hline & Male & 19.98 & 29.69 & 27.44 & 19.71 & 14.34 & 22.94 \\
\hline 2017 & Female & 6.78 & 12.69 & 29.24 & 28.86 & 24.84 & 15.57 \\
\hline & Male & 20.11 & 28.40 & 28.13 & 19.97 & 12.75 & 22.80 \\
\hline 2018 & Memale & 6.65 & 14.21 & 28.05 & 29.44 & 20.35 & 15.22 \\
\hline & Fale & 18.88 & 24.63 & 24.43 & 18.63 & 13.44 & 20.60 \\
\hline & Female & 5.95 & 11.37 & 27.37 & 28.19 & 17.45 & 13.73 \\
\hline & Male & 21.60 & 27.67 & 27.79 & 19.39 & 12.94 & 23.24 \\
\hline
\end{tabular}

Firstly, we investigated the relationship between the percentage of hyperlipidemia and age. The results showed that the prevalence of hyperlipidemia increased steadily with aging, no matter with the gender. For the male, the percentages of hyperlipidemia peaked in the 41-50y group. However, it had a maximum value for the female in the 61-70y group, which was consistent with the levels of serum TG. Secondly, we investigated whether the percentage of hyperlipidemia increased from 2012 to 2019 in each age group. Through the Trend chi-square test, we found that the percentages of hyperlipidemia of male didn't exhibit a linear increase in all the age groups during the 8 years. However, the percentages of hyperlipidemia of female in the $\leq 40,41-50,51-60$ and 61-70 year groups increased steadily from 2012 to 2019 (Trend chi-squares 54.55, 7.45, 29.55 and 7.61 , respectively, all $p<0.05)$.

The incidence rates of hyperglycemia in the control group from 2012 to 2019 were listed in Table 5. The percentages of hyperglycemia also exhibited an age-dependent increase markedly in both genders. Similar to the levels of serum GLU, the percentages of hyperglycemia of male were always higher than those of the age-matched female. It should be noticed that the percentages of hyperglycemia of female increased more rapidly with aging than that of male. Such as, in 2013, the percentage of hyperglycemia of male was 4.91 folds as that of female in the $\leq 40$ year group; but, it was only 1.28 folds as 
that of female in the $\geq 71$ year group. Furthermore, through the Trend chi-square test, the prevalence of hyperglycemia of male increased steadily in the $\leq 40$ and 61-70 year groups from 2012 to 2019 (Trend chi-square 27.21 and 14.10, respectively, both $p<0.05$ ). And the percentages of hyperlipidemia of female didn't show differences in all the age groups in the consecutive 8 years.

Table 5

Percentages of hyperglycemia in the control group from 2012 to 2019

\begin{tabular}{|clllllll|}
\hline Age group & $\mathbf{5 4 0 y}$ & $\mathbf{4 1 - 5 0 y}$ & $\mathbf{5 1 - 6 0 y}$ & $\mathbf{6 1 - 7 0 y}$ & $\mathbf{2 7 1 y}$ & Total \\
\hline 2012 & Male & 1.80 & 8.46 & 14.10 & 16.28 & 20.20 & 7.84 \\
\hline & Female & 0.64 & 2.37 & 7.12 & 10.39 & 17.22 & 3.97 \\
\hline 2013 & Male & 2.03 & 7.72 & 15.00 & 16.54 & 20.40 & 8.00 \\
\hline \multirow{2}{*}{2014} & Female & 0.46 & 2.94 & 7.11 & 10.75 & 15.17 & 3.69 \\
\hline & Male & 1.94 & 7.77 & 13.71 & 16.04 & 18.83 & 7.89 \\
\hline 2016 & Memale & 0.52 & 2.90 & 6.67 & 9.87 & 14.78 & 3.80 \\
\hline & Male & 2.11 & 7.41 & 13.41 & 17.27 & 19.65 & 8.66 \\
\hline 2017 & Female & 0.47 & 2.76 & 6.79 & 10.93 & 17.49 & 4.23 \\
\hline & Male & 3.16 & 7.63 & 14.24 & 14.08 & 18.69 & 8.33 \\
\hline \multirow{2}{*}{2019} & Female & 0.57 & 2.68 & 6.06 & 9.29 & 17.37 & 4.01 \\
\hline & Male & 2.58 & 8.81 & 15.05 & 19.71 & 23.35 & 9.34 \\
\hline & Female & 0.70 & 2.91 & 6.69 & 11.37 & 19.09 & 4.44 \\
\hline
\end{tabular}

\section{Effect of annual health examination on the prevalence of hyperlipidemia and hyperglycemia}

The incidence rates of hyperlipidemia in 2019 of the control group, the 1st and 8th year of the follow-up group were listed in Table 6. Compared with the non-consecutive group in 2019, there was only a significant difference of the percentages of hyperlipidemia of female in the 8 th year of the follow-up group in the $\leq 40 \mathrm{y}$ group $(p<0.05)$. Compared with the 1 st year, the incidence rates of hyperlipidemia of both genders in the 8 th year increased steadily in the $\leq 40$ year group (both $p<0.05$ ). It should be noticed that, for the female under the age of 60 , the percentages of hyperlipidemia in the 8 th year were significantly higher than those in the 1 st year of the follow-up group (all $p<0.05$ ). These were in accordance with the change pattern of serum TC in female of the follow-up group completely. As a whole, the percentages of hyperlipidemia of female in the 8th year showed significant increase compared with the 1st year of the follow-up group and 2019 of the control group (all $p<0.05$ ). For the male, there were no differences of the percentages of hyperlipidemia among these three groups. 
Table 6

Percentages of hyperlipidemia in 2019 of the control group, the 1st and 8th year of the follow-up group

\begin{tabular}{|c|c|c|c|c|c|c|c|}
\hline \multicolumn{2}{|c|}{ Age group } & \multirow{2}{*}{$\begin{array}{l}\leq 40 y \\
21.60\end{array}$} & \multirow{2}{*}{$\begin{array}{l}41-50 y \\
27.67\end{array}$} & \multirow{2}{*}{$\begin{array}{l}51-60 y \\
27.79\end{array}$} & \multirow{2}{*}{\begin{tabular}{|l|l|}
$61-70 y$ \\
19.39
\end{tabular}} & \multirow{2}{*}{$\begin{array}{l}\geq 71 y \\
12.94\end{array}$} & \multirow{2}{*}{$\begin{array}{l}\text { Total } \\
23.24\end{array}$} \\
\hline 2019 & Male & & & & & & \\
\hline & Female & 6.79 & 14.39 & 30.61 & 29.59 & 20.98 & 15.33 \\
\hline \multirow[t]{2}{*}{$1 \mathrm{st}$} & Male & 18.17 & 24.88 & 26.62 & 19.02 & 13.04 & 21.25 \\
\hline & female & 4.89 & 10.94 & 20.36 & 27.24 & 18.85 & 12.23 \\
\hline \multirow[t]{2}{*}{ 8th } & Male & $22.39^{\#}$ & 26.88 & 25.00 & 20.35 & 15.77 & 22.67 \\
\hline & Female & $8.70^{\star}, \#$ & $14.38^{\#}$ & $24.03^{\#}$ & 27.52 & 22.56 & $18.10^{\star}, \#$ \\
\hline \multicolumn{8}{|c|}{ *: $p<0.05$ compared with age-matched group in 2019 of the control group } \\
\hline
\end{tabular}

The incidence rates of hyperglycemia in 2019 of the control group, the 1st and 8th year of the follow-up group were listed in Table 7. Compared with the control group in 2019, there were significant differences of the percentages of hyperglycemia of female in the 8th year in most of the age groups (all $p<0.05$ ), consistent with serum GLU of female. Additionally, compared with the 1 st year, the percentages of hyperglycemia in the 8th year increased significantly in the 61-70 and $\geq 71$ year groups for the male and in the 41-50 and 61-70 year groups for the female, respectively (all $p<0.05$ ). On the whole, the percentages of hyperglycemia in the 8th year showed significant increase compared with the 1st year of the follow-up group and 2019 of the control group (all $p<0.05$ ), which was present in both genders.

Table 7

Percentages of hyperglycemia in 2019 of the control group, the 1 st and 8 th year of the follow-up group

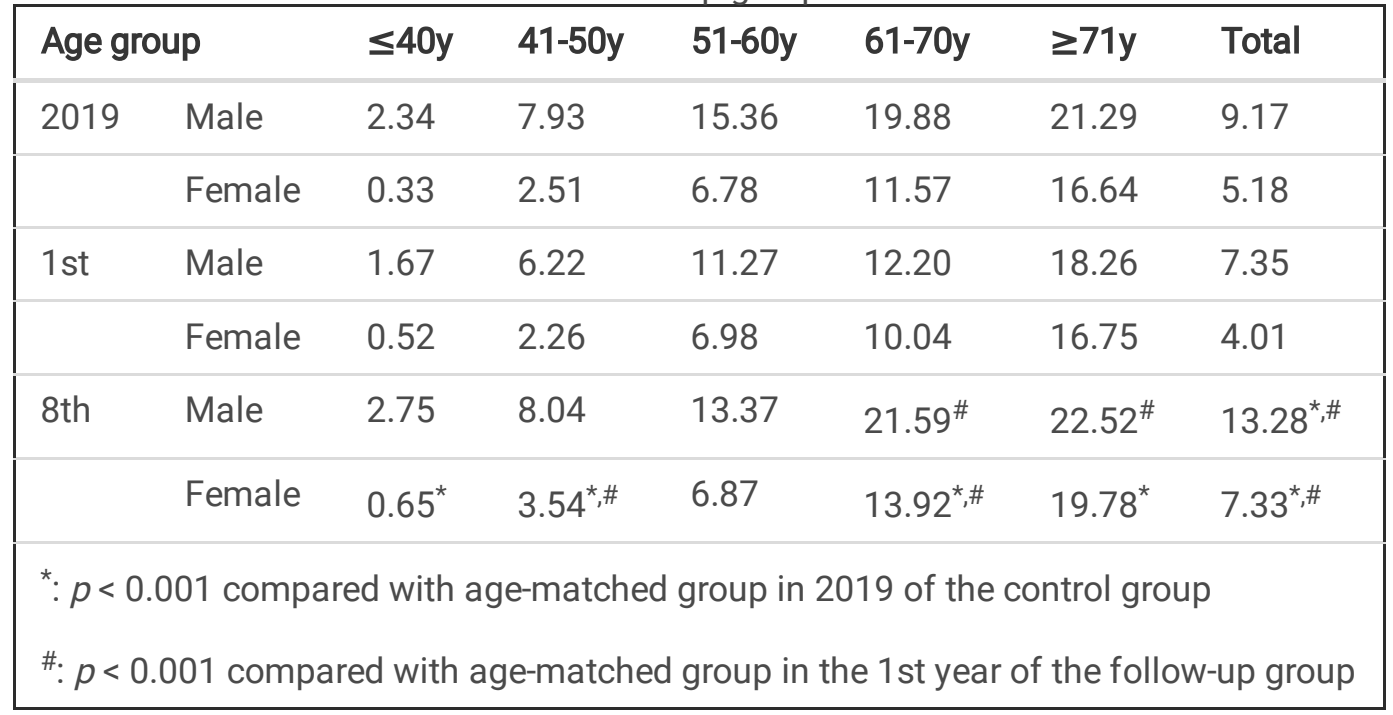

Among the total 5043 participants, 2285 (45.31\%) had been diagnosed as hyperlipidemia from 2012 to 2019. Of them, $1107(1107 / 2285,48.45 \%)$ had been hyperlipidemia 1 or 2 times and $1168(1168 / 2285,51.12 \%)$ had a bad hyperlipidemia control (over 3 times). Additionally, of the 5043 participants, 752 (14.91\%) had been diagnosed as hyperglycemia. Of them, $318(318 / 752,42.29 \%)$ had been hyperglycemia 1 or 2 times and 434 (434/752, 57.71\%) had a bad hyperglycemia control. 


\section{Discussion}

Regular physical examination is recommended in China to protection and treatment of CVD and DM, but its effectiveness in the control of hyperlipidemia and hyperglycemia has not been proved. So, we firstly investigated the changing pattern of serum lipids and glucose in the general population with aging. Since the concentrations of serum lipids and glucose in some groups didn't distribute normally, all the results were expressed as the median (interquartile range). It was found that serum TG of male exhibited the pattern of first increase, then decrease. serum TG of female showed an obvious increase with aging, similar to the report of Gan [12]. The change pattern of serum LDL-C was in accordance with serum TC in both genders, which peaked in 51-60y group and decreased after menopausal period. Serum HDL-C followed the pattern of first decrease and then increase with aging. Serum glucose in both genders demonstrated an age-dependent increasing pattern, consistent with the previous reports [13-14]. Our research further confirmed that the highest increase of serum lipids and glucose in women took place during the menopausal period. Therefore, annual health examination was also recommended for the female after menopausal period to prevent and treat the CVD and DM.

We evaluated the effectiveness of annual health examination to hyperlipidemia and hyperglycemia control through 3 approaches. After 8 years' consecutive health examination, the levels of serum lipids and glucose in the follow-up group was not lower than those of the control group in 2019. Additionally, our results showed that serum TG and TC of the 8th year increased significantly compared with the 1st year of the follow-up group, which was consistent with the report of Gan [12]. However, we demonstrated that there was no significant difference of serum GLU between the 8th and the 1th year of the follow-up group, which was unlike with the result of Gan. In our study, serum GLU in the 1th year of the follow-up group were similar to those of the control groups in all the age groups, but serum GLU in the 1 th year of the follow-up group were much lower than those in 2016 of the control groups in Gan [12].

All these results suggested that annual health examination didn't reduce the levels of serum TG, TC and GLU and prevent the development of CVD and DM. Moreover, the percentages of hyperlipidemia and hyperglycemia in the 8th year showed significant increase compared with the 1 st year of the follow-up group and 2019 of the control group (all $p<0.05$ ). Therefore, these results indicated that after 8 years' consecutive health examination, annual health examination didn't perform a positive effect in the prevention of hyperlipidemia and hyperglycemia.

With the development of economy, the prevalence of adult obesity and central obesity increased annually from 1997 to 2011 [15]. Then, the prevalence of dyslipidemia and diabetes have increased remarkably in China recently. In recent years, lines of evidence from epidemiological investigations, clinical and experimental research emerged showing that lifestyle management such as diet and exercise promoted the improvement of hyperlipidemia and hyperglycemia [16-18]. Kelly RB. reported that regular aerobic exercise had beneficial effects on lipid levels, particularly if performed for at least 120 minutes per week in 2010 [19]. Li G et al. reported that a 6-year lifestyle intervention programme for Chinese people with impaired glucose tolerance could reduce incidence of cardiovascular and all-cause mortality and diabetes [20]. These findings further confirmed that the long-term of lifestyle intervention induced clinical benefits for patients with impaired glucose tolerance and lifestyle interventions should be as public health measures to control the consequences of diabetes. Therefore, American Diabetes Association established Lifestyle Management: Standards of Medical Care in Diabetes-2019 in 2019 [21].

It is widely known that the purpose of annual health examination is to find and treat the diseases as early as possible. Early or mild hyperlipidemia and hyperglycemia will not lead to any discomfort to the body. Once one patient is diagnosed as hyperlipidemia or hyperglycemia, diet control and lifestyle improvement have been the basic measures for the treatment of dyslipidemia and diabetes. However, for a health examination participant, compliance of diet control and lifestyle management was usually poor, which has become a common problem at present. Our results also indicated that more than half participants diagnosed as hyperlipidemia and hyperglycemia had a bad control. Consistent with our results, Lau et al. found that a general population to participate in a repeated screening and lifestyle counselling programme over five years did not result in lower incidence of diabetes after 10years of follow-up [22]. So, it is necessary to perform a population-

Page $11 / 14$ 
based education on health eating and physical activity. Health management should be paid more attention to prevent cardiovascular disease and diabetes.

\section{Conclusions}

In conclusion, our data showed that annual health examination didn't show a positive effect in the prevention of hyperlipidemia and hyperglycemia. Health management should be paid more attention to prevent cardiovascular disease and diabetes.

\section{Abbreviations}

TG

Triglyceride

TC

Total cholesterol

LDL-C

Low density lipoprotein cholesterol

HDL-C

High density lipoprotein cholesterol

GLU

Glucose

CVD

Cardiovascular diseases

DM

Diabetes mellitus

LIS

Laboratory information system

\section{Declarations}

\section{Ethics approval and consent to participate}

The experimental protocol was carried out in accordance with the relevant guidelines and regulations of the Institutional Ethics Committee of Beijing Tongren Hospital affiliated Capital Medical University. All ethical principles of the Helsinki ethical declaration have been met and written informed consent was obtained from all the participants.

\section{Consent for publication}

Not applicable.

\section{Availability of data and materials}

The data used in the study were available from the LIS of Department of Clinical Laboratory of Beijing Tongren Hospital affiliated Capital Medical University.

\section{Competing interests}

Xiaohong Zhang, Xiaokui He, Xuehong Zhou, Hongyan Geng and Xiangyi Liu declare that they have no conflict of interest.

\section{Funding}


Not applicable.

\section{Authors' contributions}

Xiaohong Zhang designed the experiments, analyzed the data and wrote the manuscript. Xiaokui He, Xuehong Zhou and Hongyan Geng took part in the detection of samples. XiangYi Liu contributed to interpretation of results and reviewed drafts of the manuscript. All authors read and approved the final manuscript.

\section{Acknowledgements}

We would like to thank Mei Wang (Department of Clinical Laboratory, Beijing Tongren Hospital, Capital Medical University, Beijing, China) for advice and suggestions on the manuscript.

\section{References}

1. Liu S, LiY, ZengX, Wang H, Yin P, Wang L, et al. Burden of Cardiovascular Diseases in China, 1990-2016: Findings From the 2016 Global Burden of Disease Study. JAMA Cardiol. 2019; 4(4):342-352. doi: 10.1001/jamacardio.2019.0295.

2. Stary HC, Chandler AB, Glagov S, Guyton JR, Jr WI, Rosenfeld ME, et al. A definition of initial, fatty streak, and intermediate lesions of atherosclerosis. A report from the Committee on Vascular Lesions of the Council on Arteriosclerosis, American Heart Association. Circulation. 1994; 89(5):2462-2478. doi: 10.1161/01.cir.89.5.2462.

3. Erin D Michos, John W McEvoy, Roger S Blumenthal. Lipid Management for the Prevention of Atherosclerotic Cardiovascular Disease. N Engl J Med. 2019; 381(16):1557-1567. doi: 10.1056/NEJMra1806939.

4. Yang F, Ma Q, Ma B, Jing W, Liu J, Guo M, et al. Dyslipidemia prevalence and trends among adult mental disorder inpatients in Beijing, 2005-2018: A longitudinal observational study. Asian J Psychiatr. 2021; 57:102583. doi: 10.1016/j.ajp.2021.102583.

5. National Center for Disease Control and Prevention, National Health and Family Planning Commission. Nutrition and Chronic Diseases of Chinese Residents (2015) [M]. Beijing People's Medical Publishing House, 2015.

6. Moran A, Gu D, Zhao D, Coxson P, Wang YC, Chen CS, et al. Future cardiovascular disease in china: markov model and risk factor scenario projections from the coronary heart disease policy model-China. Circ Cardiovasc Qual Outcomes. 2010; 3(3):243-52. doi: 10.1161/CIRCOUTCOMES.109.910711.

7. Joint Committee issued Chinese guideline for the management of dyslipidemia in adults. 2016 Chinese guideline for the management of dyslipidemia in adults. Zhonghua Xin Xue Guan Bing Za Zhi. 2016; 44(10):833-853. doi: 10.3760/cma.j.issn.0253-3758.2016.10.005.

8. Wang Q, Zhang X, Fang L, Guan Q, Guan L, Li Q. Prevalence, awareness, treatment and control of diabetes mellitus among middle-aged and elderly people in a rural Chinese population: A cross-sectional study. PLoS One. 2018; 13(6):e0198343. doi: 10.1371/journal.pone.0198343.

9. Zoungas S, Arima H, Gerstein HC, Holman RR, Woodward M, Reaven P, et al. Effects of intensive glucose control on microvascular outcomes in patients with type 2 diabetes: a meta-analysis of individual participant data from randomised controlled trials. Lancet Diabetes Endocrinol. 2017; 5(6):431-437. doi: 10.1016/S2213-8587(17)30104-3.

10. Sun X, Chen Y, Tong X, Feng Z, Wei L, Zhou D, et al. The use of annual physical examinations among the elderly in rural China: a cross-sectional study. BMC Health Serv Res. 2014; 14:16. doi: 10.1186/1472-6963-14-16.

11. Chinese Diabetes Society. Guideline for the prevention and treatment of type 2 diabetes mellitus in China (2020 edition). Chinese Journal of Diabetes Mellitus. 2021; 13:315-409.

12. Gan W, Liu Y, Luo KH, Liang SS, Wang H, Li M, et al. The prevalence change of hyperlipidemia and hyperglycemia and the effectiveness of yearly physical examinations: an eight-year study in Southwest China. Lipids in Health and Disease. 2018: 17(1):70. doi: 10.1186/s12944-018-0724-6. 
13. Loh TP, Ma S, Heng D, Khoo CM. Age-related changes in the Cardiometabolic profiles in Singapore resident adult population: findings from the National Health Survey 2010. PLoS One. 2016; 11(8):e0162102. doi: 10.1371/journal.pone.0162102.

14. Wang L, Gao P, Zhang M, Huang Z, Zhang D, Deng Q, et al. Prevalence and Ethnic Pattern of Diabetes and Prediabetes in China in 2013. JAMA. 2017; 317(24):2515-2523. doi: 10.1001/jama.2017.7596.

15. Zhou L, Cao D, Si Y, Zhu X, Du L, Zhang Y, et al. Income-related inequities of adult obesity and central obesity in China: evidence from the China Health and Nutrition Survey 1997-2011. BMJ Open. 2020; 10(10): e034288. doi: 10.1136/bmjopen-2019-034288.

16. Doughty KN, Del Pilar NX, Audette A, Katz DL. Lifestyle Medicine and the Management of Cardiovascular Disease. Curr Cardiol Rep. 2017; 19(11):116. doi: 10.1007/s11886-017-0925-Z.

17. Alkhatib A, Tsang C, Tiss A, Bahorun T, Arefanian H, Barake R, et al. Functional Foods and Lifestyle Approaches for Diabetes Prevention and Management. Nutrients. 2017; 9(12):1310. doi: 10.3390/nu9121310.

18. Eckel RH, Jakicic JM, Ard JD, Jesus JM, Miller MH, Hubbard VS, et al. 2013 AHA/ACC guideline on lifestyle management to reduce cardiovascular risk: a report of the American College of Cardiology/American Heart Association Task Force on Practice Guidelines. Circulation. 2014; 129(25 Suppl 2):S76-99. doi: 10.1161/01.cir.0000437740.48606.d1.

19. Kelly RB. Diet and exercise in the management of hyperlipidemia. Am Fam Physician.2010; 81:1097-102.

20. Li G, Zhang P, Wang J, An Y, Gong Q, Gregg EW, et al. Cardiovascular mortality, all-cause mortality, and diabetes incidence after lifestyle intervention for people with impaired glucose tolerance in the Da Qing Diabetes Prevention Study: a 23-year follow-up study. Lancet Diabetes Endocrinol. 2014; 2(6):474-80. doi: 10.1016/S2213-8587(14)70057-9.

21. American Diabetes Association. Lifestyle Management: Standards of Medical Care in Diabetes-2019. Diabetes Care. 2019; 42(Suppl 1):S46-S60. doi: 10.2337/dc19-S005.

22. Lau CJ, Pisinger C, Husemoen LLN, Jacobsen RK, Linneberg A, Jørgensen T, et al. Effect of general health screening and lifestyle counselling on incidence of diabetes in general population: Inter99 randomised trial. Prev Med. 2016; 91:172-9. doi: 10.1016/j.ypmed.2016.08.016. 